\title{
IAMJ
}

INTERNATIONAL

AYURVEDIC

MEDICAL JOURNAL

Review Article

ISSN: 2320-5091

Impact Factor: 6.719

\section{CONCEPT OF RASAYANA AND ITS UTILITY (REJUVENATION THERAPY):}

\section{A REVIEW}

\author{
Yatendra Kumar Sethi ${ }^{1}$, Gurpreet Kaur Gill ${ }^{2}$, Bhanu Pratap singh ${ }^{3}$, C.R. Yadav \\ ${ }^{1}$ PG scholar, PG department of Kriya Sharir, National Institute of Ayurveda, Jaipur, India \\ ${ }^{2}$ PG scholar, PG department of Kriya Sharir, National Institute of Ayurveda, Jaipur, India \\ ${ }^{3}$ Assistant Professor, PG department of Kriya Sharir, National Institute of Ayurveda, Jaipur, India \\ ${ }^{4}$ Associate Professor \& HOD, PG department of Kriya Sharir, National Institute of Ayurveda, Jaipur, India
}

Corresponding Author: draryansethi38@gmail.com

\section{https://doi.org/10.46607/iamj2609112021}

(Published Online: November 2021)

Open Access

(C) International Ayurvedic Medical Journal, India

Article Received: 19/10//2021 - Peer Reviewed: 10/11/2021 - Accepted for Publication: 13/11/2021

\section{Check for updates}

\begin{abstract}
Ayurveda is preponderant and antique health science of prime importance. Being a health science, it adheres to an exclusive approach that is entirely different from contemporary science. It fulfils the goal of health by focusing on maintenance of health and treatment of disease as holistic. Rasayana is an important branch of Ayurveda. It is one of the eight branches of Ayurveda (Ashtanga Ayurveda). Rasayana is useful for persons of all age groups. It is equally important in the treatment of diseases as well as in maintaining health. Given this plethora of information, it can be rightly stated that Rasayana is a boon given to the world by Ayurveda. The description of Rasayana comes in detail in all the Ayurvedic texts. This branch of Ayurveda appears to have been practised in ancient lines as an important speciality aiming at rejuvenation and geriatric care. Rasayana is one of the eight branches of Ayurveda. Rasayana Chikitsa plays a critical role in the prevention as well as cure of the disease. In Ayurveda, too much importance is given to this branch that the chapters of Rasayana find a foremost place in the Charaka Samhita Chikitsa sthana whereas in Sushruta Samhita it is pushed back to chapters 27-30 of Chikitsa sthana. In Ashtanga Hridaya Rasayana does not find a special place in Chikitsa sthana and is described only briefly in the 39th chapter of Uttar Tantra. This reflects on the declining importance of Rasayana therapy in the Samhita period itself. In Sushruta Samhita, which is otherwise considered more precise and practical has given a competitively moderate
\end{abstract}


description of the Rasayana in four chapters out of which two chapters deal with Divya Rasayana i.e., the divine drugs, which are not available today.

Keywords: Ayurveda, Ashtanga Ayurveda, Rasayana, Rejuvenation, Geriatric Care

\section{INTRODUCTION}

A long and healthy life has been canonized by human beings since antiquity. Ayurveda is an antediluvian science of life with the dual motto of maintaining the health of a healthy person and alleviating disorders of diseased ${ }^{1}$. Ayurveda remains a vital health care system even in today's metropolitan advanced world that is suggestive of its intensity and latent strength. Even in the primaeval classical period Ayurveda was already a well-developed science of medicine and was practised in the form of Astanga Ayurveda i.e., medicine with eight specialities viz. Kayachikitsa, Shalakya Tantra, Shalya Tantra, Visha, Bhoota, Kaumara, Rasayana and Vajikarana Tantra ${ }^{2}$. The bifold aim of Ayurveda can be very well furnished through the special branch Rasayana ${ }^{3}$.

\section{Etymology (Nirukti):}

The word Rasayana (Rasa +Ayana) appertains to nutrition and its transportation in the body. Ayana also may be understood as Apayana according to Yogindranatha and ergo, Rasayana may be taken as the approach or the measure to carry through replenished and excellent Dhatu within the body. Hence, it becomes evident that protocols that are utilized for the subsistence of Dhatu or dispensing strength to the latter are addressed as Rasayana. Rasayana therapy effectuates the normalcy of Rasa Dhatu and consequently sustains other Dhatu in equilibrium for a longer period ${ }^{4}$. Thus, as a result, obviates ageing and provides longevity which can be intimated as Vayasthapana or Jaranashana. Rasayana also augments individual resistance power against diseases. ${ }^{5}$

\section{Classification of Rasayana}

Acharya Sushruta has illustrated a thorough classification of Rasayana. Commentator Dalhana has ameliorated it further ${ }^{6}$ In Charaka Samhita, no such absolute classification of Rasayana is given, but a detailed narration of methods of Rasayana Therapy is available in it $^{7}$

Conforming to the mode of administration, purpose, mode of action, contents, usage and scope of various measures, Rasayana may be classified as follows:

\begin{tabular}{|c|c|}
\hline $\begin{array}{l}\text { According to the mode of ad- } \\
\text { ministration }\end{array}$ & $\begin{array}{l}\text { 1. Kuti Praveshika (Indoor Regimen) } \\
\text { 2. } \quad \text { Vatatapika (Outdoor Regimen) } \\
\text { 3. Droni Praveshika (Special Regimen) }\end{array}$ \\
\hline According to purpose & $\begin{array}{l}\text { 1. Kamya Rasayana (Promotor of normal health) } \\
\text { - Prana Kamya (Promotor of life-vitality and longevity) } \\
\text { - Medha Kamya (Promotor of intellect) } \\
\text { - Sri Kamya (Promotor of complexion and lustre) } \\
\text { 2. Naimittika Rasayana (Promotor of specific vitality in specific diseases) } \\
\text { 3. Ajasrika Rasayana (Dietary Rasayana) }\end{array}$ \\
\hline $\begin{array}{l}\text { According to the mode of ac- } \\
\text { tion }\end{array}$ & $\begin{array}{l}\text { 1. Samshodhana Rasayana } \\
\text { 2. Samshamana Rasayana }\end{array}$ \\
\hline According to Achara Rasayana & $\begin{array}{l}\text { 1. Ahara Rasayana (Dietary Modalities) } \\
\text { 2. Achara Rasayana (Behavioural Modalities) } \\
\text { 3. Dravya Rasayana (Drug based measures) }\end{array}$ \\
\hline According to Bheshja Bheda & $\begin{array}{l}\text { 1. Dravya Bhuta Rasayana (Drug Rasayana) } \\
\text { 2. Adravya Bhuta Rasayana (Non-pharmacological Rasayana) }\end{array}$ \\
\hline
\end{tabular}


In conformity with the need, indications or contraindications, these different varieties of Rasayana may be employed discreetly. An extremely remarkable response of the Rasayana therapy can be achieved if it is administered as per the norms laid down for it. Pertinent details of these types of Rasayana are expounded below:

According to the mode of administration of $R a$ sayana

Acharya Charaka depicted three methods for the administration of Rasayana therapy. These are as follows:

\section{Kuti Praveshika Rasayana (Indoor Regimen)}

A physician should adhere to the following steps before the administration of Kuti Praveshika Rasayana Rasayana. These steps include:

\section{* Kuti Nirmana ${ }^{8}$}

The Kuti Praveshika procedure is a specialised indoor regimen of Rasayana therapy. The patient is kept in specially built "Trigarbha Kuti" (Cottage).

Requirements and recommendations for the construction of Trigarbha Kuti -

\section{Suitable place:}

$>$ Place or locality inhabited by high profile persons like a king, physician, Brahamana, Saints

$>$ Dwelling place devoid of any kind of fear or terror.

$>$ Equipped with all the mandatory appliances.

$>24 / 7$ availability of physician, Brahamana and medications.

\section{Architectural Recommendations:}

$>$ Direction: Should face towards the east or the north.

Should be capacious enough.

\section{Steps for Samshodhana therapy -}

\section{Snehnna and Swedana}

Administration of Haritakyadi Yoga with lukewarm water in a dose of 1 Tola

Samsarjana Karma

Administration of Rasayana drugs - After the Samshodhana and Samsarjana Karma, suitable

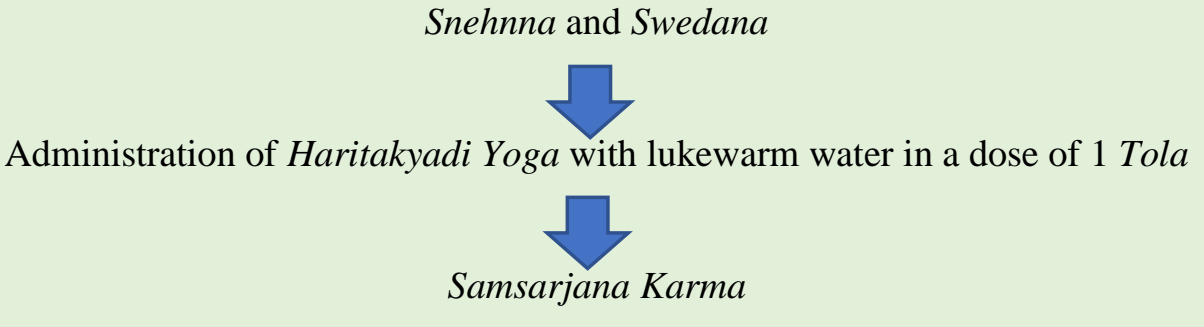

Kuti: Trigarbha (three concentric cottages)

Ventilation: To proper ventilation, it should be equipped with strait ventilators.

Walls: Thick-walled

Lighting facility: Well-lightened cottage

Season friendly: It should be cordial to reside in all seasons.

Noise proof: It should be devoid of any unpleasant and undesirable noise.

$>$ It should be pleasant to the mind.

$>$ Women should not be allowed to enter.

* Entrance of patient in the cottage -

The appropriate time for entrance -

- Uttrayana

- Shukla Paksha

- On an auspicious day with an auspicious constellation

- Propitious Muhurta and Karana

Protocols to be followed while entering in cottage

- Enter cottage after shaving

The person who is going to receive rejuvenation therapy should be endowed with strong determination power, memory, faith and benevolence.

- The person should be free from any mental tribulation

- The person should perform all the requisite religious acts like worshipping and perambulation of God.

Samshodhana before administration of rejuvenation therapy - Before the administration of $R a$ sayana Dravya, the body of the recipient should be cleaned by using appropriate Samashodhana therapy.

Rasayana Dravya is administered to the individual considering his age, Prakriti, Koshtha, Agni, etc. 
2. Vatatapika Rasayana (Outdoor Regimen) - This type of Rasayana can be administered outdoors as well as exposure to wind and sun does not affect it.

\section{Droni Praveshika (Special Regimen) -}

Drugs used in Droni Praveshika:

(a) Brahma Suvarchala

(b) Adityaparni

(c) Nari

(d) Kashthagodha (e) Sarpa

(f) Soma

(g) Padma

(h) Aja

(i) Nila

Droni Specifications -

* It should be prepared from the greenwood of Palasha.

* It should be smeared with Sneha.

\section{Procedure -}

Intake of Svarasa of either drug by a person to his full capacity

A person should lay down in the prepared Droni without wearing any clothes

Droni should be then covered with the lid due to which the person becomes unconscious

\section{According to purpose}

Based on the purpose, Rasayana is classified into 3 categories:

a. Kamya Rasayana

b. Naimittika Rasayana (Promotion of specific vitality in specific diseases)

c. Ajasrika Rasayana (Dietary Rasayana)
A. Kamya Rasayana Indications

- Indicated for healthy persons

Purpose

- For preservation and promotion of health.

- To promote vigour and vitality.

\section{Classification}

It is further categorized into the following three types:

\begin{tabular}{|c|c|c|}
\hline Type of Rasayana & Purpose of Rasayana & Drugs used \\
\hline 1. Prana Kamya & For the promotion of life vitality and longevity & Triphala Rasayana, Haritaki Rasayana \\
\hline 2. Medha Kamya & For the promotion of intellect and mental functions & Brahmi, Shankhpushpi \\
\hline 3. Sri Kamya & $\begin{array}{l}\text { For the promotion of strength, vigour, complexion and } \\
\text { lustre }\end{array}$ & Amalki Rasayana, Loha Rasayana \\
\hline
\end{tabular}

\section{B. Naimittika Rasayana}

\section{Indications}

- Indicated for both healthy and deceased persons.

\section{Purpose}

For healthy persons

- Promotion of Oja, Ayu, and media.

\section{For patients}

- Mitigation of diseases.

- Promotion of health. 
Drug specific Naimittika Rasayana Dravya

\begin{tabular}{|l|l|l|}
\hline Sr. No. & Disease & Drugs used \\
\hline 1 & Eye diseases (Especially vision-related disorders.) & Jyotismati, Triphala, Shatavari, Yashtimadhu \\
\hline 2 & Heart Disease & Shalaparni \\
\hline 3 & Skin ailments and Kushtha & Tuvarak, Bhallataka, Vidanga, Somaraji, Gandhaka \\
\hline 4 & Granthi and gulma & Pippati, Bhallataka \\
\hline 5 & Yakshma & Rasona, Nagabala, Shilajatu, Pippaladi \\
\hline 6 & Pandu & Loha \\
\hline 7 & Shvasa & Agastya Rasayana, Bhallataka \\
\hline 8 & Aamvata & Amrita Bhallataka \\
\hline 9 & Vata Vyadhi & Rasona, Guggalu, Bala, Nagbala \\
\hline 10 & Prameha & Shilajatu, haridra, Amalaki \\
\hline 11 & Medoroga & Guggulu, Haritaki \\
\hline 12 & Raktagata Vata & Rasona, Bala, Rasna, Medhya Rasayana \\
\hline 13 & Nimna rakatchap & Kasturi, Kupilu, \\
\hline 14 & Shitapitha & Haridra \\
\hline
\end{tabular}

\section{Ajasrika Rasayana}

\section{Elements of Rasayana Therapy in Ayurveda}

Samsamana group of Rasayanas are used in larger extent in comparison to Samsodhana Rasayanas e.g., Nagabala, Cayavanaprasa, Brahma Rasayana, Amalaki Rasayana, Bhringaraj, Guduci, Brahmi, Bhallataka, Pippali, Gambhari, Silajatu, Sankhapuspi, Triphala Rasayana, Yaştimadhu and Punarnava etc. This type of Rasayana drugs promote longevity, intellect, strength and lusture of the body. These Rasayanas are used in a routine fashion.

4. Achara Rasayana (Conduct Rasayana): Ayurveda identifies at least three distinct modalities of Rasayana to optimise cellular nutrition and thereby attain rejuvenation. These include

(i) Ahara Rasayana (Dietary Modalities)

(ii) Achara Rasayana (Behavioural Modalities)

(iii) Dravya Rasayana

\section{(i) Ahara Rasayana (Dietary Modalities)}

state of equilibrium the wholesome and compatible diet which is responsible to produce pure Ahara Rasa results in dynamic tissue element.

In Ayurvedic text, Acarya Dalhana in his commentary on Susruta Samhita described this type of Rasayana as Ajasrika Rasayana where it is stated that in this type of Rasayana, daily use of milk (Dugdha) and Ghee in the diet enhances the essence of tissue elements which rejuvenate the individuals.

\section{(ii) Achara Rasayana (Behavioural Modalities)}

The quality of cellular nutrition is also greatly influenced by the behaviour of the individual and this behaviour embodies somatic and psychic dimensions. For example, the significance of an exercise in $\mathrm{Ra}$ sayana. The psychic dimensions of these modalities emphasize positive mental attitudes. Traits like selfcontainment, love, compassion helping attitude etc. are considered in Ayurveda to work like Rasayana and thereby down-regulate the ageing process. Negative attitudes like anger, jealously, greed tend to cause a constriction of circulatory channels and thereby block the flow of nutrients. This can be well understood by the example of Ajirna (indigestion) caused due to a negative attitude. Rasayana therapy plays important role in the Prevention of interception wears and tears of body tissues and advocacy of total health content of an individual. Thus, Rasayana Chikitsa has got importance from both the preventive and curative aspects of the disease. ${ }^{9}$ We all want to look forever young and increase our lifespan by staying healthy. Rasayanas or vitalizers, as they are called, do the same. They replenish the vital fluids of our body, thus keeping us away from diseases. Charak starts Chikitsa Sthana with $R a$ sayan and Vajikaran giving still more priority to $R a$ sayan. The reason to which given by Chakrapani is that, as they are Mahaphaldayi and among them, $R a$ sayana is the one which endows strength and 
immunity resulting in 100/1000 years of long and contamination-free life. Persons who are truthful and free anger, who are devoid of alcohol and sex indulgence, who do not indulge in violence or exhaustion, who are peaceful and pleasing in their speech, who practise Japa ( incantation ) and cleanliness, who are dhira (stable and steady), who are regular practise charity and tapas (panance), who regularly offer prayers to the gods, cows, brahmanas, teachers, preceptors and old people, who are absolutely free from barbarous acts, who are compassionate, whose period of awakening and sleep are regular, who habitually take and milk and ghee, who are acquainted with the measurement of the country and the time, who are experts in the knowledge of rationality, who are free from ego, whose conduct is good, who are not narrow minded, who have love for spiritual knowledge, who have in excellent sense organs are conditions, who have reverence for seniors, astikas and persons having self-control and who regularly study scriptures, get the best out of rejuvenation therapy. If persons endowed with these qualities practise rejuvenation therapy, they get all the rejuvenation effects described above. ${ }^{10}$

\section{DISCUSSION}

\section{IMPORTANCE OF RASAYANA}

Details of description are available about Rasayana in classical Ayurvedic treatises. Considering newer techniques of research some very well-known Rasayana medicines are explored. Ashwagandha is well known medicinal herb used as Rasayana. ${ }^{11}$ The root extract of Ashwagandha has also shown good effect in relieving pain disability caused in patients with osteoarthritis of the knee. ${ }^{12}$ Also, the extract of leaves of Amalaki (Emblica Officinalis) is found to exert rapid protective effects against lipid peroxidation by scavenging free radicals and reducing the risk of diabetic complications. ${ }^{13}$ Amalaki is told to be the best medicine as Vayasthapana. Triphala another abundantly used medicine for various purposes also possesses Rasayana effects. Another famous Rasayana medicine Bilva has also shown strong antitumor and antioxidant activities. Some of the classical Ayurvedic formulations such as Laxmivilas Ras, Agnitundi Vati, Ajmodadi Churna,
Tribhuvankirti Rasa and Sitopladi Churna, when tested for their antioxidant effect, they were found to possess efficient scavenger of superoxide radical, and all medicines were found to possess scavenging activity and inhibitory concentration $50 \%$.

\section{CONCLUSION}

The approach of treatment that is explained by means of Rasayana is a novel concept. Hardly any of health sciences is found to have put thrust as huge as Ayurveda has. It gives an insight into what should the treatment aim at - the establishment of Dhatu Samya. Hence treatment of any disease would not be complete without using Rasayana. Use of Rasayana, specific to that disease, is mentioned in the treatment of each disease, is mentioned in each Adhyaya of Samhitas and is broadly explained in separate Adhyayas dedicated to it.

\section{REFERENCES}

1. Agnivesh, Charak Samhita, Ayurveda Dipika Commentary by Shri Chakrapanidutt Edited by Yadavji Trikam Ji Acharya, Chaukhambha Subharti Prakashan, Varanasi, Reprint 2015, Sutra Sthan 1(1)/4 Page no. 376

2. Agnivesh, Charak Samhita, Ayurveda Dipika Commentary by Shri Chakrapanidutt Edited by Yadavji Trikam Ji Acharya, Chaukhambha Subharti Prakashan, Varanasi, Reprint 2015, Sutra Sthan 1(1)/4 Page no. 376

3. Agnivesh, Charak Samhita, Ayurveda Dipika Commentary by Shri Chakrapanidutt Edited by Yadavji Trikam Ji Acharya, Chaukhambha Subharti Prakashan, Varanasi, Reprint 2015, Sutra Sthan 30/26 page 187

4. Agnivesh, Charak Samhita, Ayurveda Dipika Commentary by Shri Chakrapanidutt Edited by Yadavji Trikamji Acharya, Chaukhambha Subharti Prakashan, Varanasi, Reprint 2015, Sutra Sthan 1(1)/4 Page 376

5. Sushurta, Sushruta Samitha with Nibandha Sangraha Commentary by Sri Dalhana Acharya and Nyayachandrika Panjika commentary on Nidana Sthana by Sri Gayadasa Acharya edited by Vaidya Yadavaji Trikamji Acharya, Chaukhambha Orientaliya, Varanasi, Reprint Edition 2019, Sutra Sthana 14/13, page 498

6. Sushurta, Sushruta Samitha with Nibandha Sangraha Commentary by Sri Dalhana Acharya and Nyayachandrika Panjika commentary on Nidana Sthana by Sri 
Gayadasa Acharya edited by Vaidya Yadavaji Trikamji Acharya, Chaukhambha Orientaliya, Varanasi, Reprint Edition 2019, Sutra Sthana 27/2, page 498

7. Agnivesh, Charak Samhita, Ayurveda Dipika Commentary by Shri Chakrapanidutt Edited by Yadavji Trikam Ji Acharya, Chaukhambha Subharti Prakashan, Varanasi, Reprint 2015, Sutra Sthan 1(1)/16, Page 377

8. Agnivesh, Charak Samhita, Ayurveda Dipika Commentary by Shri Chakrapanidutt Edited by Yadavji Trikam Ji Acharya, Chaukhambha Subharti Prakashan, Varanasi, Reprint 2015, Sutra Sthan 1(1)/17-24, Page 377

9. Agnivesh, Charak Samhita, Ayurveda Dipika Commentary by Shri Chakrapanidutt Edited by Yadavji Trikam Ji Acharya, Chaukhambha Subharti Prakashan, Varanasi, Reprint 2015, Sutra Sthan 1(4)/30, Page 388

10. Agnivesh, Charak Samhita, Ayurveda Dipika Commentary by Shri Chakrapanidutt Edited by Yadavji Trikam Ji Acharya, Chaukhambha Subharti Prakashan, Varanasi, Reprint 2015, Sutra Sthan 1(4)/31-35, Page 388

11. Raja SS, Manivasagam T, Sankar V, Prakash S, Muthusamy R, Krishnamurti A, Surendran S. Withania somnifera root extract improves catecholamines and physiological abnormalities seen in a Parkinson's disease model mouse. J Ethnopharmacol, Sep 25, 2009; 125(3): 369-73.

12. Ramakanth GSH, Uday Kumar C, Kishan PV, Usharani P. A randomized, double-blind, placebo-controlled study of efficacy and tolerability of Withaina somnifera extracts in knee joint pain. JAIM, 2016; 7(4): 151-157.

13. Nain P, Saini V, Sharma S, Nain J. Antidiabetic and antioxidant potential of Emblica Officinalis Gaertn. leaves extract in streptozotocin-induced type-2 diabetes mellitus (T2DM) rats. J Ethnopharmacol, Jun 26, 2012; 142(1): 65-71.

\section{Source of Support: Nil Conflict of Interest: None Declared}

How to cite this URL: Yatendra Kumar Sethi et al: Concept Of Rasayana And Its Utility (Rejuvenation Therapy): A Review. International Ayurvedic Medical Journal \{online\} 2021 \{cited November 2021\} Available from: http://www.iamj.in/posts/images/upload/2808_2814.pdf 